EXPERIMENTAL STUDY

\title{
Novel neuroanatomical pathways for thyroid hormone action in the human anterior pituitary
}

\author{
Anneke Alkemade ${ }^{1,2}$, Edith C Friesema ${ }^{3}$, George G Kuiper ${ }^{3}$, Wilmar M Wiersinga ${ }^{1}$, Dick F Swaab ${ }^{2}$, Theo J Visser ${ }^{3}$ \\ and Eric Fliers ${ }^{1,2}$ \\ ${ }^{1}$ Department of Endocrinology and Metabolism, Academic Medical Center, University of Amsterdam, Amsterdam, 1105 AZ, The Netherlands, \\ ${ }^{2}$ Netherlands Institute for Brain Research, Amsterdam, 1105 AZ, The Netherlands and ${ }^{3}$ Department of Internal Medicine, Erasmus MC, Rotterdam, \\ The Netherlands \\ (Corresponding should be addressed to E Fliers; Email: e.fliers@amc.uva.nl)
}

\begin{abstract}
Objective: An increasing number of proteins appear to be involved in thyroid hormone feedback action at the level of the anterior pituitary, but the cell types expressing these proteins are largely unknown. The aim of the present study was to identify cell types in the human anterior pituitary that express type II and type III deiodinase (D2 and D3), the recently described thyroid hormone transporter (MCT8) and thyroid hormone receptor (TR) isoforms by means of double-labeling immunocytochemistry.

Results: We found TR isoforms to be expressed most prominently in gonadotropes and - although to a lesser extent - in thyrotropes, corticotropes, lactotropes and somatotropes. D3 staining showed a distribution pattern that was remarkably similar. By contrast, D2 immunoreactivity was observed exclusively in folliculostellate (FS) cells showing coexpression with human leukocyte antigen (HLA), a marker of major histocompatibility complex (MHC)-class II. MCT8 immunostaining was present in FS cells without HLA coexpression.

Conclusions: From these results, we propose a novel neuroanatomical model for thyroid hormone feedback on the human pituitary, with a central role for FS cells in thyroid hormone activation, which thus play an important role in the suppression of TSH secretion by circulating thyroxine $\left(\mathrm{T}_{4}\right)$.
\end{abstract}

European Journal of Endocrinology 154 491-500

\section{Introduction}

The importance of thyroid hormone feedback action at the level of the anterior pituitary has been clearly established. Thyroid hormones modulate thyroid-stimulating hormone (TSH) release from the anterior pituitary within the framework of a negative feedback loop, and an increasing number of proteins appear to be involved in this feedback action. About $50 \%$ of tri-iodothyronine $\left(\mathrm{T}_{3}\right)$, the biologically active form of thyroid hormone, is produced locally by conversion of thyroxine $\left(\mathrm{T}_{4}\right)(1)$. In the human pituitary, type II deiodinase (D2) converts $\mathrm{T}_{4}$ into $\mathrm{T}_{3}$, while type III deiodinase (D3) converts $\mathrm{T}_{4}$ and $\mathrm{T}_{3}$ into inactive metabolites $(2,3)$. We have recently described the presence of both D2 and D3 activity in the human anterior pituitary (4). Type I deiodinase activity does not appear to play a major role in thyroid hormone feedback in the human anterior pituitary (3). $\mathrm{T}_{3}$ acts by binding to thyroid hormone receptor (TR) isoforms, which have been reported in both human and rat anterior pituitary $(5,6)$. In rats, TR $\beta 2$ is prominent in somatotropic and thyrotropic cells (7). Monocarboxylate transporter 8 (MCT8), a thyroid hormone transporter with a higher affinity for $\mathrm{T}_{3}$ than for $\mathrm{T}_{4}$ in man, may play an important role in the anterior pituitary by providing cells with thyroid hormone (8). However, no information is available at present on cells expressing these proteins in the human anterior pituitary.

Animal studies support a functional role of D2 and TRs in the endocrine feedback regulation of thyroid hormone. During hypothyroidism, a large increase in $\mathrm{D} 2$ and TR $\beta 2$ expression occurs in the rat anterior pituitary $(9,10)$. Furthermore, a role for MCT8 in thyroid hormone feedback is suggested by the high serum TSH levels in the face of highly elevated serum $\mathrm{T}_{3}$ levels recently reported in children with mutations or deletions in the MCT8 gene $(11,12)$. In addition to clear effects on TSH secretion, changes in the serum concentrations of other glycoprotein hormones from the anterior pituitary have been reported during altered thyroid hormone status. For example, serum follicle-stimulating hormone (FSH) is elevated in primary hypothyroidism, and the response of luteinizing 
hormone (LH) to gonadotropin-releasing hormone $(\mathrm{GnRH})$ is decreased (13).

We have recently reported the distribution of $\operatorname{TR} \alpha 1$, $\alpha 2, \beta 1$ and $\beta 2$ in the human anterior pituitary, but the cell types expressing these TR isoforms remain unknown (5). Likewise, no data are available on cell types expressing deiodinases or MCT8 in the human anterior pituitary. In the human hypothalamus TR isoforms, D3 and MCT8 are all expressed in hypophysiotropic TRH neurons of the paraventricular nucleus (PVN), whereas D2 is expressed mainly in glial cells (4).These data suggest that hypothalamic $\mathrm{T}_{3}$ production and action occur in different cell types. Whether similar anatomical routes are present in the anterior pituitary is unknown. In the present study, we identified cell types expressing D2, D3, MCT8 and TR isoforms in the human anterior pituitary by fluorescent double-labeling immunocytochemistry using polyclonal rabbit antisera directed against TR $\alpha 1, \mathrm{TR} \alpha 2, \mathrm{TR} \beta 1, \mathrm{TR} \beta 2, \mathrm{D} 2, \mathrm{D} 3$ and MCT8 in combination with mouse monoclonal markers for pituitary hormones and folliculostellate (FS) cells. On the basis of the data obtained, we propose a novel neuroanatomical model for thyroid hormone feedback action in the human anterior pituitary.

\section{Materials and methods}

\section{Pituitary material}

We studied five human anterior pituitaries by immunocytochemistry. Tissues were obtained from the Netherlands Brain Bank at the Netherlands Institute for Brain Research (NIBR) in accordance with the formal permissions for brain autopsy and the use of human brain material and clinical information for research purposes. Clinicopathologic data are presented in Table 1. Tissues were obtained after a postmortem delay of 5-10 h. Our earlier studies have shown that in human pituitary tissue with a comparable postmortem delay both D2 and D3 enzyme activity can still be detected (4). Pituitary samples were fixed in $10 \%$ phosphate-buffered formalin at room temperature (RT) for 4 weeks (Table 1). Tissues were dehydrated in a graded ethanol series, cleared in xylene and embedded in paraffin. Sections of $6 \mu \mathrm{m}$ were made on a microtome.

\section{Antisera}

For immunocytochemical staining, we used polyclonal rabbit antisera raised against synthetic peptides derived from rat D2 (nos. 763: 247-266 and 762: 247-262 $(14,15)$ (kindly provided by Dr J L Leonard, University of Massachusetts Medical Center, Worcester, MA, USA) and human D3 (no. 676: 265-278) and MCT8 (nos. 1305 and 1306: 527-539). Polyclonal antisera for D3 and MCT8 were raised in rabbits by Eurogentec SA (Herstal, Belgium) after conjugation of the synthetic peptide to keyhole limpet hemocyanin. Antiserum from the final bleed was used without further purification.

Specificity of the antisera was supported by absence of staining with the preimmune serum and after preadsorption with homologous peptides. Cross-reactivity of the antibodies was assessed by preadsorption with heterologous peptides. In addition, Western blotting on human anterior pituitary and, for TR antibodies, Western blotting of tissues of knockout mice were performed. These data have been published earlier $(4,5$, 15-18). Mouse monoclonal pituitary markers were obtained from Biogenesis (Poole, UK) (FSH, LH, TSH, $\mathrm{GH}$, prolactin (PRL) and adrenocorticotropic hormone (ACTH)), and DAKO Diagnostics (Glostrup, Denmark) (human leukocyte antigen (HLA)-DR).

\section{Immunocytochemical staining}

Sections were mounted on Superfrost Plus slides and subsequently dried for at least 2 days at $37^{\circ} \mathrm{C}$. After deparaffinization in xylene and rehydration through a graded ethanol series, sections were rinsed in distilled water and in Tris-buffered saline (TBS, $3 \times 10 \mathrm{~min}$ ). Sections used for D3 or TR isoform staining were microwave-treated in TBS for $10 \mathrm{~min}$ at $700 \mathrm{~W}$ (19). Immunocytochemistry for morphologic studies of cell types was performed in the following steps:

1. incubation with the first antibody (D2 1:1250; MCT8 1:500 in Supermix (SUMI, 0.05 M Tris,

Table 1 Clinicopathological data.

\begin{tabular}{|c|c|c|c|c|c|}
\hline Subject no. & Sex & Age (years) & PMD (hours) & Fix (days) & Cause of death and clinical diagnosis \\
\hline 95101 & $\mathrm{~F}$ & 73 & 6 & 31 & Heart failure, type II diabetes, angina pectoris \\
\hline 96082 & M & 74 & 8 & 27 & Unknown, Parkinson's disease \\
\hline 95102 & M & 53 & 10 & 31 & $\begin{array}{l}\text { Circulatory failure, unsuccessful resuscitation, } \\
\text { cardiac tamponnade after surgery for aorta dissection }\end{array}$ \\
\hline 96081 & $\mathrm{~F}$ & 63 & 5 & 28 & $\begin{array}{l}\text { Respiratory insufficiency, astrocytoma in the left } \\
\text { hemisphere and brainstem }\end{array}$ \\
\hline 96084 & $\mathrm{~F}$ & 78 & 8 & 32 & $\begin{array}{l}\text { Respiratory insufficiency, emphysema, hypothyroidism } \\
\text { (thyroxine treatment, daily dose } 0.125 \mathrm{mg} \text { ) }\end{array}$ \\
\hline
\end{tabular}

Fix: fixation duration; PMD: postmortem delay. 
$0.15 \mathrm{M} \mathrm{NaCl}, 0.5 \%$ Triton X-100 (Sigma) and $0.25 \%$ gelatin (Merck) (pH 7.6)), D3 1:900 in SUMI containing 1\% BSA, TR $\alpha 1$ 1:1000, TR $\alpha 2$ 1:2000, TR $\beta 1$ 1:1000, TR $\beta 2$ 1:1000 in SUMI containing $5 \%$ milk) for $1 \mathrm{~h}$ at RT and subsequently overnight at $4{ }^{\circ} \mathrm{C}$

2. rinsing in TBS $(3 \times 10 \mathrm{~min})$

3. incubation in biotinylated goat-antirabbit (1:400 in SUMI), for $1 \mathrm{~h}$ at RT

4. rinsing in TBS $(3 \times 10 \mathrm{~min})$

5. incubation in avidine-biotinylated complex (1:800 in SUMI) for $1 \mathrm{~h}$ at RT

6. rinsing in TBS $(3 \times 10 \mathrm{~min})$

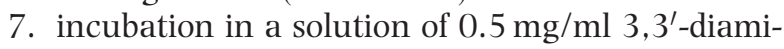
nobenzidine (DAB) (Sigma) in a total volume of $15 \mathrm{ml}$ TBS containing $0.01 \% \mathrm{H}_{2} \mathrm{O}_{2}$ (Merck) and $0.035 \mathrm{~g} / \mathrm{ml}$ ammonium nickel sulfate $(\mathrm{BDH}$, Poole, UK) for approximately $15 \mathrm{~min}$ at RT.

The reaction was stopped in distilled water. Subsequently, sections were dehydrated through a graded ethanol series, cleared in xylene, and coverslipped with Entellan (Merck).

Colocalization studies were performed by immunocytochemistry using immunofluorescence. This technique appeared to be less sensitive than the protocol with DAB as a chromogen; therefore, antibody concentrations were increased. The protocol consisted of the following steps:

1. incubation with first antibody (rabbit polyclonal anti-D2, D3, MCT8 or TR isoform 1:300), combined with a monoclonal mouse pituitary marker (TSH, FSH, LH, GH, PRL, HLA undiluted and ACTH 1:20 in SUMI for $1 \mathrm{~h}$ at RT and subsequently overnight at $4^{\circ} \mathrm{C}$

2. rinsing with $\mathrm{TBS}(3 \times 10 \mathrm{~min})$

3. incubation with biotinylated goat anti-rabbit (1:400 in SUMI) for $1 \mathrm{~h}$ at RT

4. rinsing with TBS $(3 \times 10 \mathrm{~min})$

5. incubation in avidin biotinylated complex (Vector, ABC, Burlingame, CA, USA 1:800 in SUMI) for $1 \mathrm{~h}$ at RT

6. rinsing with TBS $(3 \times 10 \mathrm{~min})$

7. incubation in biotinylated tyramide (1:750 in SUMI).

Staining was visualized with either $\mathrm{Cy} 2$ and streptavidin-coupled $\mathrm{Cy} 3$, or $\mathrm{Cy} 3$ and streptavidin-coupled $\mathrm{Cy} 2$ as fluorophore.

\section{Results}

D2, D3, TR $\alpha 1, T R \beta 1$ and TR $\beta 2$ staining showed an inhomogeneous distribution in the anterior pituitary. Cells expressing these proteins were clustered, whereas cells showing MCT8 and TR $\alpha 2$ immunoreactivity were more uniformly distributed over the anterior pituitary. Staining intensity for deiodinases, TR $\alpha 1$ and $\operatorname{TR} \beta$ showed strong interindividual variation, whereas TR $\alpha 2$ and MCT8 staining was intense in all patients studied. Immunocytochemical staining for all antibodies with DAB-Ni for visualization is shown in Fig. 1. TR isoform and D3 immunoreactivity were present in the cytoplasm of granular cells showing prominent colocalization with FSH (Figs 2 and 3). TR $\alpha 2$ and TR $\beta 2$ showed clear colocalization with TSH (Fig. 2). D3 showed sporadic coexpression with TSH. D2 and MCT8 immunoreactivity was prominent in FS cells showing no colocalization with pituitary hormones (Figs 1 and 3). Coexpression of D2 and HLA immunoreactivity was observed, although not all D2-expressing cells coexpressed HLA. MCT8 immunoreactivity, which was present in stellate-shaped cells, as we concluded from inspection of DAB-Ni-stained sections, did not colocalize with HLA immunoreactivity.

One patient (no. 96084) diagnosed with hypothyroidism and treated with $\mathrm{T}_{4}$ showed very low TSH immunoreactivity as compared with all other patients. The limited number of TSH-positive cells did not show coexpression with TRs. TR isoforms were expressed in other hormone-secreting cells in this patient. Deiodinase and MCT8 staining was not different from that in pituitaries of other subjects. Results are summarized in Table 2.

\section{Discussion}

In the present study, we have characterized cells in the anterior pituitary that express deiodinases, $\mathrm{T}_{3}$ receptor isoforms and MCT8 thyroid hormone transporter. Specificity of the antisera has been described before and was supported by testing of the preimmune serum, preadsorption with the synthetic peptide and Western blotting on human anterior pituitary $(4,5)$. Specificity of the TR isoform antisera was further supported by Western blotting in knockout mice $(4,17,18)$.

D2 and MCT8 immunoreactivity were observed in FS cells (Fig. 3). FS cells are agranular cells of the anterior pituitary with long cytoplasmic processes between endocrine cells and are able to modulate anterior pituitary hormone secretion (20-22). We found that HLA, a determinant of major histocompatibility complex (MHC)-class II, which is expressed in a subset of FS cells $(10-20 \%)(21,22)$, colocalized with D2 immunoreactivity. These results strongly suggest that a subset of FS cells produce $\mathrm{T}_{3}$ from $\mathrm{T}_{4}$ and may be capable of transporting T3 to other cells expressing TR isoforms. MCT8 and a subset of D2-expressing FS cells did not coexpress HLA. Recently, expression of nestin, in rat anterior pituitary was described in nontypical FS cells (23). Whether these cells also express MCT8 and D2 remains to be clarified.

Our present findings in the human anterior pituitary gland may seem at variance with earlier experimental studies in rats by Koenig et al., who attempted to 

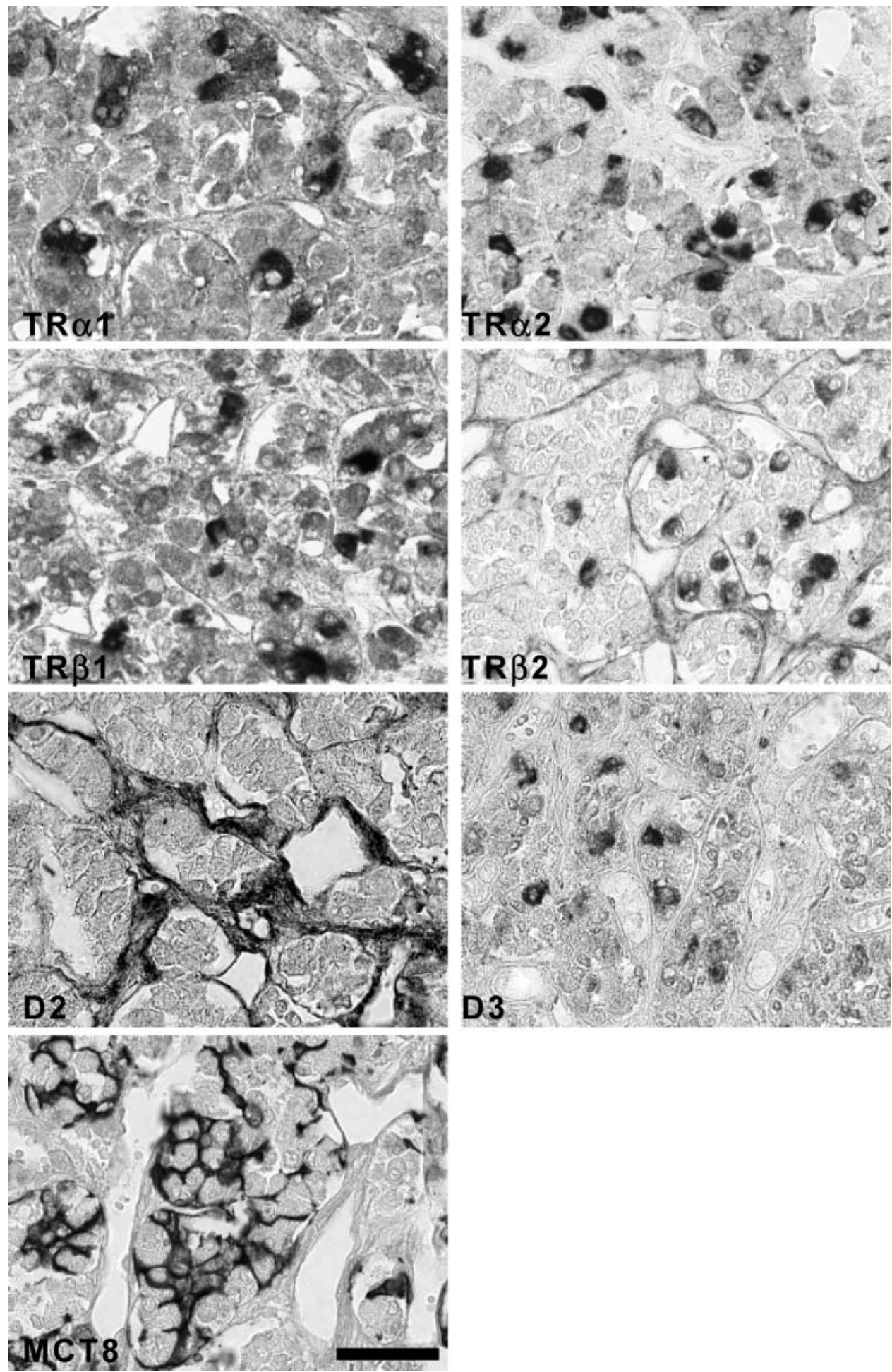

Figure $1 \mathrm{Immunostaining} \mathrm{in} \mathrm{human} \mathrm{anterior} \mathrm{pituitary} \mathrm{visualized} \mathrm{with} \mathrm{DAB-NI.} \mathrm{Bar:} 50 \mu \mathrm{m}$.

identify cell types expressing D2 in enriched cell pools obtained by gradient centrifugation of cultured rat anterior pituitary cells (24). The experiments pointed to somatotropes and mammotropes as main cell types expressing $\mathrm{T}_{3}$-responsive $\mathrm{D} 2$ activity (25). However, these cell fractions contained both hormone-secreting cells and agranular cells of the anterior pituitary; therefore, the representation of FS cells in these 

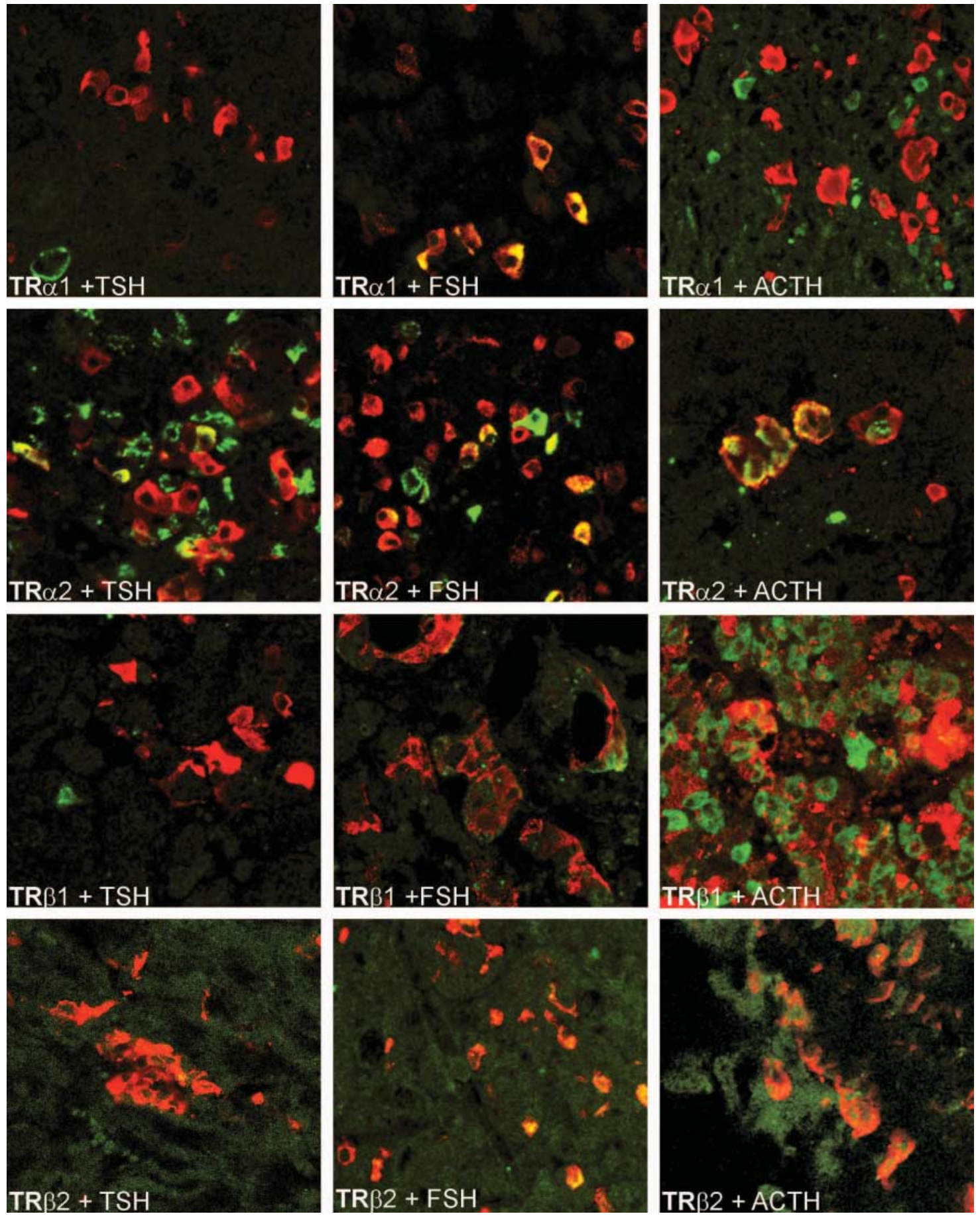

Figure 2 TR immunostaining combined with pituitary markers. Cells expressing TR isoforms are stained green, and cells expressing pituitary marker are stained red. Coexpression results in yellow staining. TR isoforms show colocalization with pituitary hormones, but not with HLA, indicating that changes in pituitary glycoprotein serum concentrations during thyroid disease may be, at least partly, based upon a direct action of thyroid hormone. Magnification $=63 \times$ objective.

experiments cannot be excluded with certainty. More recent studies in rat pituitary tumor cells showed that D2 is expressed in hormone-secreting tumor cells (26). However, it remains to be established that D2 is also expressed in hormone-secreting cells of normal rat anterior pituitary. It therefore remains unknown at present whether the finding of D2 expression in FS cells of the human anterior pituitary gland represents an interspecies difference, or, alternatively, whether D2 expression may also be present in rat FS cells. 

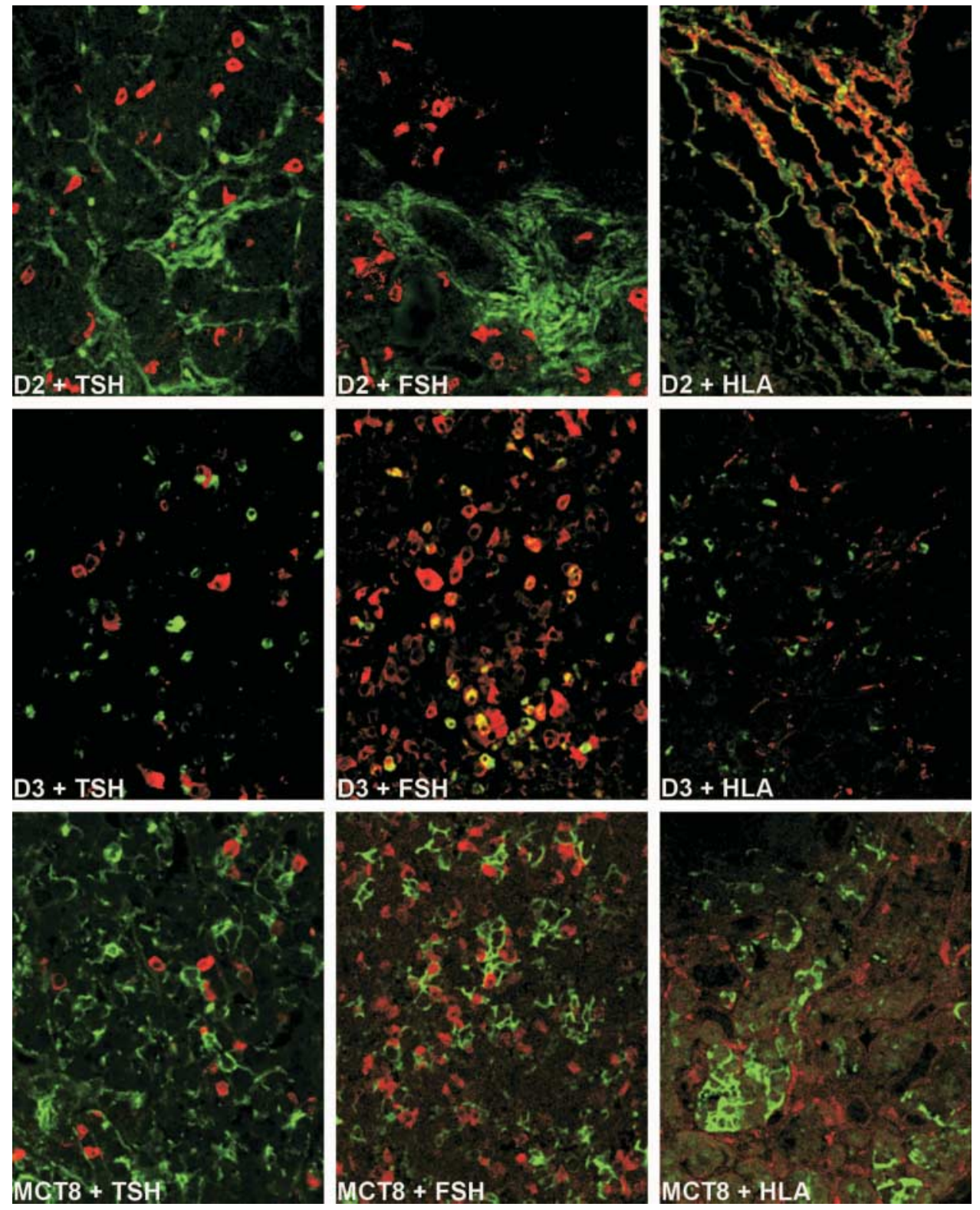

Figure 3 Deiodinase and MCT8 immunostaining combined with pituitary markers. Cells expressing deiodinases are stained green, and cells expressing pituitary markers are stained red. Coexpression results in yellow staining. Note the colocalization of D2 with HLA. Magnification $=63 \times$ objective.

Table 2 Expression of thyroid hormone-related proteins in pituitary cells.

\begin{tabular}{lcccccccc}
\hline & TSH & FSH & LH & GH & ACTH & PRL & MHC-II FS cells & Other FS cells $^{*}$ \\
\hline D2 & - & - & - & - & - & - & + & + \\
D3 & + I & + & + & + & + & - & - & - \\
MCT8 & - & - & - & - & - & - & - & - \\
TR 1 1 & - & + & + & - & - & + & - & - \\
TR 2 2 & + & + & + & + & + & - & - & - \\
TR 1 1 & - & + & + & + & + & - & - & - \\
TR32 & + & + & + & + & + & + & & - \\
\hline
\end{tabular}

FS cells: folliculostellate cells. *D2, D3 and MCT8 expression in MHC-II cells was determined by double-labeling studies; other expression in FS cells was determined by morphologic studies. 
We have previously described both nuclear and cytoplasmic TR staining in the human anterior pituitary (5). Although TRs have been assumed to be largely confined to the nuclear compartment (27), we found mainly cytoplasmic staining. Cytoplasmic localization of TRs has also been described in rats with the antisera that were used in this study $(17,18)$. More recent studies have shown that TRs may shuttle rapidly between the nuclear and cytoplasmic compartment (28). Translocation of the TR is suggested to be ligand dependent (29) and to require multiple protein interaction with various cofactors (30).

Different TR isoforms may have different roles in thyroid hormone function. In somatotropes, $\mathrm{T}_{3}$ increases TR $\alpha 1$, while it decreases $\operatorname{TR} \beta 2(7,31)$. Serum TSH concentrations are not altered in mice lacking all TR $\alpha$ transcripts (32). This is in contrast with TR $\beta$ knockout mice, which have increased TSH subunit mRNA content in the anterior pituitary. This suggests a specific role for TR $\beta$ in the negative feedback of thyroid hormone on TSH $(33,34)$. A specific role for TR $\beta 2$ in TSH regulation is also supported by our data. TR $\beta 2$ shows clear coexpression with TSH, while TSH coexpression with the other ligand-binding TR isoforms was not found.

Earlier studies in rats showed the most prominent expression of TR $\beta 2$ in somatotropes and thyrotropes (7), whereas, in the present study on human postmortem material, most prominent TR $\alpha$ and $\beta$ expression was observed in gonadotropes. The difference in expression may reflect an interspecies difference, or it may be related to the presence of severe illness in the patients in the present study. During severe illness, serum concentrations of $\mathrm{T}_{3}$ (and eventually $\mathrm{T}_{4}$ ) decrease without giving rise to elevated TSH levels. This phenomenon is known as nonthyroidal illness (NTI) (35).

The pathogenesis of NTI is still unclear, but decreased TRH expression at the level of the hypothalamus suggests a major change in central thyroid hormone feedback regulation, contributing to persistently low serum TSH (36). Whether sporadic D3 staining in thyrotropes, as found in the present study, reflects downregulation of D3 enzyme activity in the framework of NTI is unknown. One might speculate that decreased degradation of $\mathrm{T}_{3}$ in thyrotropes represents an additional contribution to inappropriately low serum TSH concentrations during illness. However, to establish whether altered TR or deiodinase expression in the anterior pituitary plays a role in the pathogenesis of NTI requires quantitative studies in tissues of patients with a biochemically defined endocrine status before death. Although expression levels of proteins may have been affected by critical illness in these patients, it is unlikely that distribution patterns are influenced by NTI.

A number of endocrine changes have been described in patients with thyroid dysfunction. Hypomenorrhea has been reported in hyperthyroid women and hypermenorrhea in hypothyroid women. LH, FSH and GH levels are often increased during hyperthyroidism $(37,38)$. CRH responsiveness of the corticotrope is increased in hypothyroid patients (39). The presence of TRs in somatotropes, corticotropes and gonadotropes indicates that changes in pituitary glycoproteins may be based, at least partly, upon a direct action of thyroid hormone on these hormone-secreting cells in the anterior pituitary. In the present study, a patient (no. 96084 ) treated with $\mathrm{T}_{4}$ for primary hypothyroidism appeared to have relatively low TSH expression. This may be related to the relative hyperthyroxinemia often present in patients on $\mathrm{T}_{4}$-supplementation therapy. We could not substantiate this in view of the lack of data on antemortem serum thyroid hormone concentrations in this patient. MCT8 and deiodinase staining were unremarkable. No colocalization was observed between TR isoforms and TSH in this patient, although TR isoforms were expressed in the anterior pituitary. The lack of colocalization between TR isoforms and TSH can possibly be explained by decreased TSH expression, but it may also be the result of downregulation of TR expression in thyrotropes in this patient.

This study reports the anatomical distribution of deiodinases, MCT8 and TRs in the human anterior pituitary for the first time. From the results, we propose a novel neuroanatomical route for thyroid hormone feedback action on hormone-secreting cells of the human anterior pituitary. In this model, the FS cell is central in local hypophyseal $\mathrm{T}_{3}$ production (Fig. 4). The expression of the TSH receptor reported earlier in MHC-class II cells (40) and the increase in D2 activity that has been observed in TSH-producing tumors (41) suggests that D2 expression in the anterior pituitary can be influenced directly by TSH. This is further supported by a dose-dependent increase of D2 mRNA by TSH, which has been reported in human thyroid cells and the presence of a cAMP response element in the D2 promoter (42).

The absence of D2 from cell types that express thyroid hormone receptors indicates that production and action of $\mathrm{T}_{3}$ in man occurs in separate cell types. A similar neuroanatomical separation has been reported in both rat and human hypothalamus, where D2 and TR isoforms are differentially expressed as well $(4,5$, 43-45). Both TR isoforms and D3 expression appear to be present in hormone-secreting cells of the anterior pituitary. The overlap between TR isoform and D3 expression suggests that thyroid hormone action and degradation may occur in the same hormone-secreting cells, while $\mathrm{T}_{4}$ conversion to $\mathrm{T}_{3}$ occurs in a subset of FS cells of the anterior pituitary and may be stimulated by TSH via TSH-R binding. This fits very well with the ultrashort feedback loop regulation of TSH, as proposed by Prummel et al. (40).

MCT8 did not show colocalization with anterior pituitary hormones. Double labeling with HLA in human anterior pituitary and immunostaining in the 


\section{FS cell (HLA -ve)}

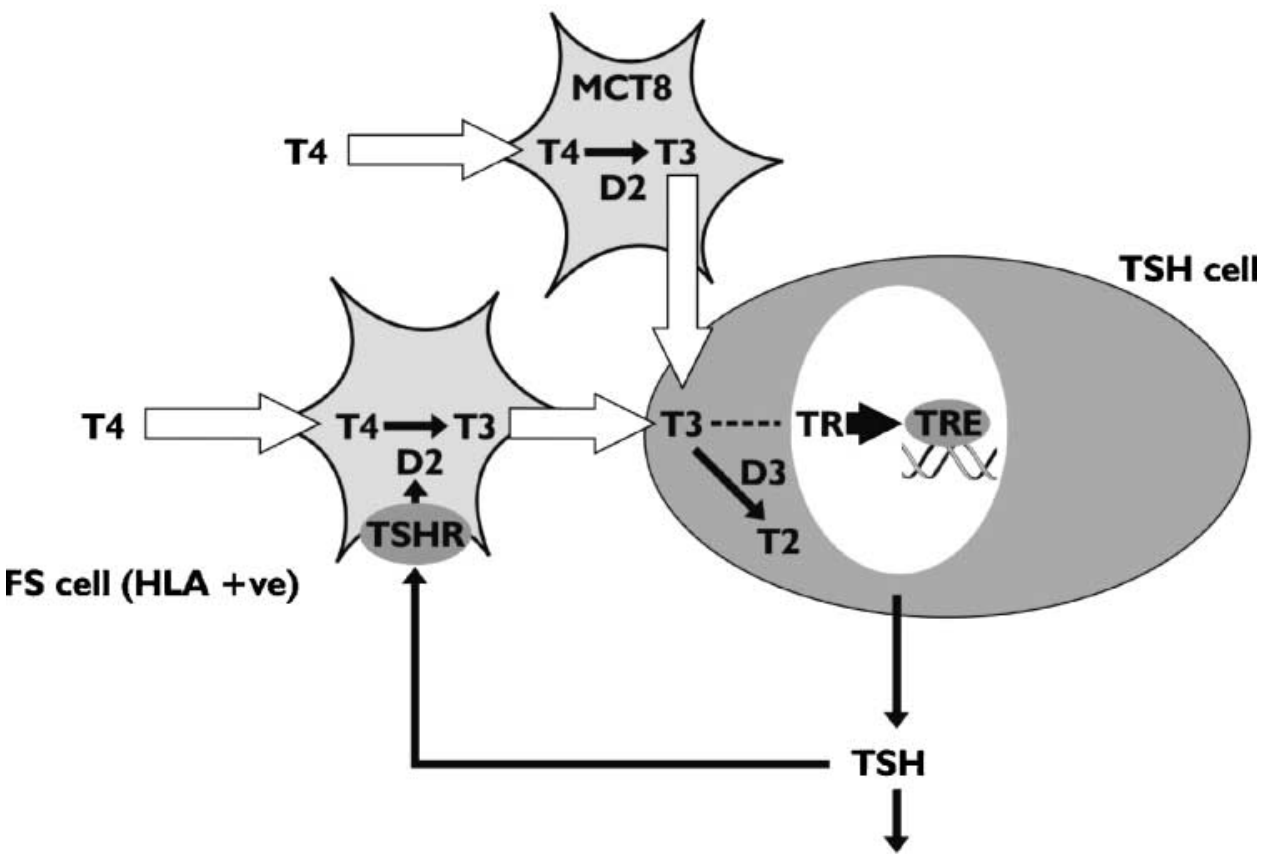

Figure 4 Proposed model for thyroid hormone action on hormone-secreting cells of the anterior pituitary. $\mathrm{T}_{4}$ is taken up by FS cells (FS cells) and is converted by type II deiodinase (D2) into $\mathrm{T}_{3}$ in HLA-positive (+ve) or -negative (-ve) FS cells. TSH can stimulate D2 expression via binding to the TSH receptor (TSHR) in HLA-positive cells. $T_{3}$ is subsequently transported to hormone-secreting cells that coexpress thyroid hormone receptor isoforms (TRs). $T_{3}$ can bind to the TR and alter gene expression, or may be degraded locally by D3.

The role of MCT8 is unclear at present. MCT8 may be involved in $\mathrm{T}_{4}$ transport into, or in $\mathrm{T}_{3}$ release from, $\mathrm{HLA}$ negative cells.

MHC-class II-expressing FS cell line were absent. Therefore, the subtype of FS cells expressing MCT8 remains to be identified. The absence of distribution overlap between MCT8 and deiodinases or TRs suggests that yet another thyroid hormone transporter may be involved in providing hormone-secreting cells of the anterior pituitary with $\mathrm{T}_{3}$. At present, the role of MCT8 in the FS cells is unknown. Human MCT8 transports $\mathrm{T}_{4}$, although not as well as $\mathrm{T}_{3}$ (Friesema et al., unpublished observations). No data have been published on the role of MCT8 in thyroid hormone efflux. In view of the involvement of other members of the MCT family in substrate efflux (46-48), a similar role for MCT8 in FS cells is an interesting possibility, requiring further investigation. Patients with a mutation in the MCT8 gene do not show a dramatic increase in TSH expression (12), as would be expected if $\mathrm{T}_{3}$ was unable to exert its negative feedback due to an inability to enter the cell. These data support our finding that MCT8 is not expressed in thyrotropes.

The present study is purely qualitative and does not allow for comparison of protein expression levels between patients. Our future studies will aim to quantify expression levels of proteins involved in thyroid hormone feedback action in the human anterior pituitary, defining their roles in situations with altered set-point regulation such as NTI.

\section{Acknowledgements}

Pituitary material was obtained from the Netherlands Brain Bank (coordinator: Dr R Ravid). Dr Jack L Leonard kindly provided us with the D2 antisera. We are indebted to B Fisser and U A Unmehopa for technical assistance. This work was supported financially by NWO-MW (grant nos. 903-40-201, 916-36-139 and 903-40194), EU-FP5 grant QLG3-CT-2000-00 930, the Brain Foundation of The Netherlands and the Ludgardine Bouwman Foundation.

\section{References}

1 Silva JE, Dick TE \& Larsen PR. The contribution of local tissue thyroxine monodeiodination to the nuclear 3,5,3'-triiodothyronine in pituitary, liver, and kidney of euthyroid rats. Endocrinology $19781031196-1207$.

2 Bianco AC, Salvatore D, Gereben B, Berry MJ \& Larsen PR. Biochemistry, cellular and molecular biology, and physiological roles of the iodothyronine selenodeiodinases. Endocrine Reviews 200223 38-89.

3 Tannahill LA, Visser TJ, McCabe CJ, Kachilele S, Boelaert K, Sheppard MC, Franklyn JA \& Gittoes NJ. Dysregulation of iodothyronine deiodinase enzyme expression and function in human pituitary tumours. Clinical Endocrinology (Oxford) 2002 $56735-743$.

4 Alkemade A, Friesema EC, Unmehopa UA, Fabriek BO, Kuiper GG, Leonard JL, Wiersinga WM, Swaab DF, Visser TJ \& Fliers E. Neuroanatomical pathways for thyroid hormone feedback in the human hypothalamus. Journal of Clinical Endocrinology and Metabolism $2005904322-4334$.

5 Alkemade A, Vuijst CL, Unmehopa UA, Bakker O, Vennstrom B, Wiersinga WM, Swaab DF \& Fliers E. Thyroid hormone receptor expression in the human hypothalamus and anterior pituitary. Journal of Clinical Endocrinology and Metabolism $200590904-912$.

6 Yen PM, Sunday ME, Darling DS \& Chin WW. Isoform-specific thyroid hormone receptor antibodies detect multiple thyroid hormone receptors in rat and human pituitaries. Endocrinology 1992 $1301539-1546$. 
7 Childs GV, Taub K, Jones KE \& Chin WW. Triiodothyronine receptor beta- 2 messenger ribonucleic acid expression by somatotropes and thyrotropes: effect of propylthiouracil-induced hypothyroidism in rats. Endocrinology $19911292767-2773$.

8 Friesema EC, Ganguly S, Abdalla A, Manning Fox JE, Halestrap AP \& Visser TJ. Identification of monocarboxylate transporter 8 as a specific thyroid hormone transporter. Journal of Biological Chemistry $200327840128-40135$.

9 Li M \& Boyages SC. Expression of beta2-thyroid hormone receptor in euthyroid and hypothyroid rat pituitary gland: an in situ hybridization and immunocytochemical study. Brain Research 1997773 125-131.

10 Riskind PN, Kolodny JM \& Larsen PR. The regional hypothalamic distribution of type II $5^{\prime}$-monodeiodinase in euthyroid and hypothyroid rats. Brain Research $1987420194-198$.

11 Dumitrescu AM, Liao XH, Best TB, Brockmann K \& Refetoff S. A novel syndrome combining thyroid and neurological abnormalities is associated with mutations in a monocarboxylate transporter gene. American Journal of Human Genetics 200474 168-175.

12 Friesema EC, Grueters A, Biebermann H, Krude H, von Moers A, Reeser M, Barrett TG, Mancilla EE, Svensson J, Kester MH, Kuiper GG, Balkassmi S, Uitterlinden AG, Koehrle J, Rodien P, Halestrap AP \& Visser TJ. Association between mutations in a thyroid hormone transporter and severe X-linked psychomotor retardation. Lancet $2004 \mathbf{3 6 4} 1435-1437$.

13 Meikle AW. The interrelationships between thyroid dysfunction and hypogonadism in men and boys. Thyroid 200414 (Suppl 1) S17-S25.

14 Diano S, Leonard JL, Meli R, Esposito E \& Schiavo L. Hypothalamic type II iodothyronine deiodinase: a light and electron microscopic study. Brain Research 2003976 130-134.

15 Leonard JL, Leonard DM, Safran M, Wu R, Zapp ML \& Farwell AP. The mammalian homolog of the frog type II selenodeiodinase does not encode a functional enzyme in the rat. Endocrinology 1999 $1402206-2215$.

16 Kuiper GG, Klootwijk W \& Visser TJ. Substitution of cysteine for selenocysteine in the catalytic center of type III iodothyronine deiodinase reduces catalytic efficiency and alters substrate preference. Endocrinology $2003 \mathbf{1 4 4} 2505-2513$.

17 Zandieh Doulabi B, Platvoet-ter Schiphorst M, van Beeren HC, Labruyere WT, Lamers WH, Fliers E, Bakker O \& Wiersinga WM. TR(beta) 1 protein is preferentially expressed in the pericentral zone of rat liver and exhibits marked diurnal variation. Endocrinology $2002143979-984$.

18 Zandieh-Doulabi B, Dop E, Schneiders M, Schiphorst MP, Mansen A, Vennstrom B, Dijkstra CD, Bakker O \& Wiersinga WM. Zonal expression of the thyroid hormone receptor alpha isoforms in rodent liver. Journal of Endocrinology $2003179379-385$.

19 Shi SR, Cote RJ \& Taylor CR. Antigen retrieval immunohistochemistry: past, present, and future. Journal of Histochemistry and Cytochemistry $1997 \mathbf{4 5} 327-343$.

20 Allaerts W, Carmeliet P \& Denef C. New perspectives in the function of pituitary folliculo-stellate cells. Molecular and Cellular Endocrinology 199071 73-81.

21 Allaerts W \& Denef C. Regulatory activity and topological distribution of folliculo-stellate cells in rat anterior pituitary cell aggregates. Neuroendocrinology 198949 409-418.

22 Baes M, Allaerts W \& Denef C. Evidence for functional communication between folliculo-stellate cells and hormone-secreting cells in perifused anterior pituitary cell aggregates. Endocrinology 1987 $120685-691$.

23 Krylyshkina O, Chen J, Mebis L, Denef C \& Vankelecom H. Nestinimmunoreactive cells in rat pituitary are neither hormonal nor typical folliculo-stellate cells. Endocrinology $2005 \mathbf{1 4 6}$ $2376-2387$.

24 Koenig RJ, Leonard JL, Senator D, Rappaport N, Watson AY \& Larsen PR. Regulation of thyroxine $5^{\prime}$-deiodinase activity by $3,5,3^{\prime}$-triiodothyronine in cultured rat anterior pituitary cells. Endocrinology $1984115324-329$.
25 Koenig RJ \& Watson AY. Enrichment of rat anterior pituitary cell types by metrizamide density gradient centrifugation. Endocrinology $1984115317-323$.

26 Kim SW, Harney JW \& Larsen PR. Studies of the hormonal regulation of type $25^{\prime}$-iodothyronine deiodinase messenger ribonucleic acid in pituitary tumor cells using semiquantitative reverse transcription-polymerase chain reaction. Endocrinology 1998 $1394895-4905$.

27 Carlson DJ, Strait KA, Schwartz HL \& Oppenheimer JH. Thyroid hormone receptor isoform content in cultured type 1 and type 2 astrocytes. Endocrinology $1996137911-917$.

28 Hager GL, Lim CS, Elbi C \& Baumann CT. Trafficking of nuclear receptors in living cells. Journal of Steroid Biochemistry and Molecular Biology 200074 249-254.

29 Baumann CT, Maruvada P, Hager GL \& Yen PM. Nuclear cytoplasmic shuttling by thyroid hormone receptors. Multiple protein interactions are required for nuclear retention. Journal of Biological Chemistry $200127611237-11245$.

30 Maruvada P, Baumann CT, Hager GL \& Yen PM. Dynamic shuttling and intranuclear mobility of nuclear hormone receptors. Journal of Biological Chemistry 2003 278 12425-12432.

31 Hodin RA, Lazar MA \& Chin WW. Differential and tissue-specific regulation of the multiple rat c-erbA messenger RNA species by thyroid hormone. Journal of Clinical Investigation $1990 \mathbf{8 5}$ $101-105$.

32 Macchia PE, Takeuchi Y, Kawai T, Cua K, Gauthier K, Chassande O, Seo H, Hayashi Y, Samarut J, Murata Y, Weiss RE \& Refetoff S. Increased sensitivity to thyroid hormone in mice with complete deficiency of thyroid hormone receptor alpha. PNAS 200198 349-354.

33 Forrest D, Hanebuth E, Smeyne RJ, Everds N, Stewart CL, Wehner JM \& Curran T. Recessive resistance to thyroid hormone in mice lacking thyroid hormone receptor beta: evidence for tissue-specific modulation of receptor function. EMBO Journal $1996153006-3315$.

34 Weiss RE, Forrest D, Pohlenz J, Cua K, Curran T \& Refetoff S. Thyrotropin regulation by thyroid hormone in thyroid hormone receptor beta-deficient mice. Endocrinology $19971383624-3629$.

35 Wiersinga WM. Nonthyroidal illness. In The Thyroid, 8th edn, pp 281-295. Eds LE Braverman \& RD Utiger. Philadelphia: Lippincott, Williams \& Wilkins, 2000.

36 Fliers E, Guldenaar SE, Wiersinga WM \& Swaab DF. Decreased hypothalamic thyrotropin-releasing hormone gene expression in patients with nonthyroidal illness. Journal of Clinical Endocrinology and Metabolism $1997 \mathbf{8 2} 4032-4036$.

37 Iranmanesh A, Lizarralde G, Johnson ML \& Veldhuis JD. Nature of altered growth hormone secretion in hyperthyroidism. Journal of Clinical Endocrinology and Metabolism 199172 108-115.

38 Longcope $\mathrm{C}$. The male and female reproductive systems in thyrotoxicosis. In The Thyroid, 8th edn, pp 652-657. Eds LE Braverman \& RD Utiger. Philadelphia: Lippincott, Williams \& Wilkins, 2000.

39 Kamilaris TC, DeBold CR, Pavlou SN, Island DP, Hoursanidis A \& Orth DN. Effect of altered thyroid hormone levels on hypothalamic-pituitary-adrenal function. Journal of Clinical Endocrinology and Metabolism $198765994-999$.

40 Prummel MF, Brokken LJ, Meduri G, Misrahi M, Bakker O \& Wiersinga WM. Expression of the thyroid-stimulating hormone receptor in the folliculostellate cells of the human anterior pituitary. Journal of Clinical Endocrinology and Metabolism 200085 $4347-4353$

41 Baur A, Buchfelder M \& Kohrle J. Expression of 5'-deiodinase enzymes in normal pituitaries and in various human pituitary adenomas. European Journal of Endocrinology $2002 \mathbf{1 4 7}$ 263-268.

42 Murakami M, Araki O, Hosoi Y, Kamiya Y, Morimura T, Ogiwara T, Mizuma H \& Mori M. Expression and regulation of type II iodothyronine deiodinase in human thyroid gland. Endocrinology 2001142 2961-2967. 
43 Lechan RM, Qi Y, Jackson IM \& Mahdavi V. Identification of thyroid hormone receptor isoforms in thyrotropin-releasing hormone neurons of the hypothalamic paraventricular nucleus. Endocrinology $199413592-100$.

44 Tu HM, Kim SW, Salvatore D, Bartha T, Legradi G, Larsen PR \& Lechan RM. Regional distribution of type 2 thyroxine deiodinase messenger ribonucleic acid in rat hypothalamus and pituitary and its regulation by thyroid hormone. Endocrinology $1997 \mathbf{1 3 8}$ 3359-3368.

45 Tu HM, Legradi G, Bartha T, Salvatore D, Lechan RM \& Larsen PR Regional expression of the type 3 iodothyronine deiodinase messenger ribonucleic acid in the rat central nervous system and its regulation by thyroid hormone. Endocrinology $1999 \mathbf{1 4 0}$ 784-790.

46 Daberkow RL, White BR, Cederberg RA, Griffin JB \& Zempleni J. Monocarboxylate transporter 1 mediates biotin uptake in human peripheral blood mononuclear cells. Journal of Nutrition $20031332703-2706$.

47 Manning Fox JE, Meredith D \& Halestrap AP. Characterisation of human monocarboxylate transporter 4 substantiates its role in lactic acid efflux from skeletal muscle. Journal of Physiology 2000529 (Pt 2) 285-293.

48 Wilson MC, Jackson VN, Heddle C, Price NT, Pilegaard H, Juel C, Bonen A, Montgomery I, Hutter OF \& Halestrap AP. Lactic acid efflux from white skeletal muscle is catalyzed by the monocarboxylate transporter isoform MCT3. Journal of Biological Chemistry 1998273 15920-15926.

Received 7 October 2005

Accepted 22 December 2005 